\title{
Obesity and cardiovascular disease risk factors in Tehran adults: a population-based study
}

$$
\begin{aligned}
& \text { F. Azizi, }{ }^{1} \text { A. Esmaillzadeh }{ }^{1} \text { and P. Mirmiran }{ }^{1}
\end{aligned}
$$

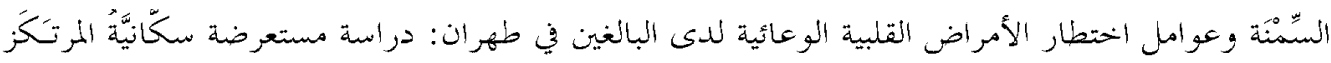

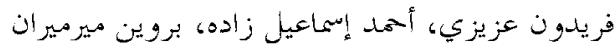

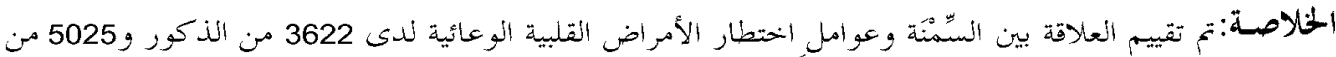

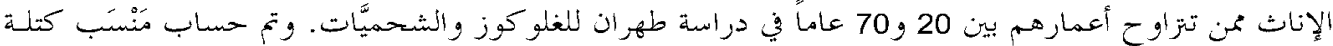

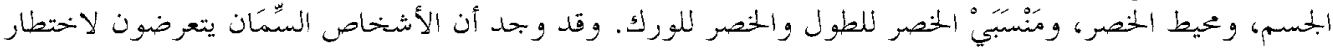

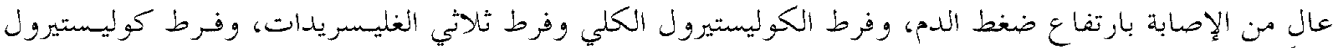

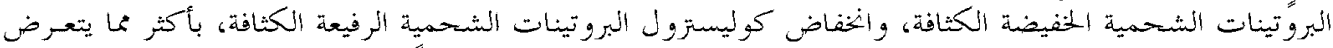

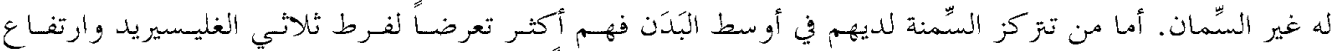

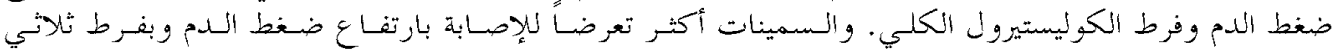

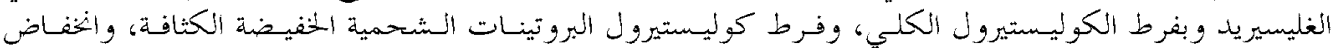

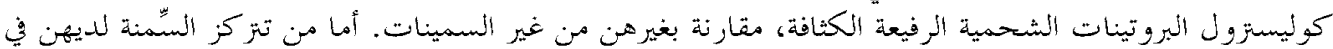

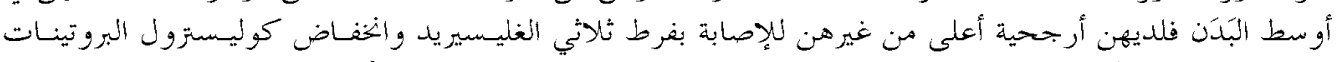

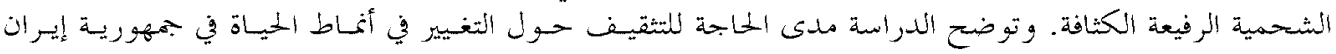

$$
\begin{aligned}
& \text { الإسلامية. }
\end{aligned}
$$

ABSTRACT The relationship between obesity and cardiovascular disease risk factors was assessed in 3622 males and 5025 females aged 20-70 years. Body mass index, waist circumference, waist-to-height and waist-to-hip ratios were calculated. Obese men had a higher risk of hypertension, high total cholesterol (TC), high triglycerides (TG), high low-density lipoprotein cholesterol (LDL-C) and low high-density lipoprotein cholesterol (HDL-C) levels than non-obese men. Centrally obese men were more susceptible to high $\mathrm{TG}$, hypertension and high TC. Obese women had a higher chance of being hypertensive and having high total TC, high TG, high LDL-C and low HDL-C levels than non-obese females. Centrally obese women had higher odds for high TG and low HDL-C. There is a need for education about lifestyle change in the country.

\begin{abstract}
Obésité et facteurs de risque de maladies cardio-vasculaires chez l'adulte à Téhéran :étude transversale dans une population définie

RÉSUMÉ La relation entre l'obésité et les facteurs de risque de maladies cardio-vasculaires a été évaluée chez 3622 hommes et 5025 femmes âgés de 20 à 70 ans. L'indice de masse corporelle, le tour de taille, le rapport tour de taille/taille et le rapport tour de taille/tour de hanches ont été calculés. Les hommes obèses avaient un risque plus élevé d'hypertension, de cholestérol total élevé, de triglycérides élevés, de cholestérol des lipoprotéines de basse densité (LDL) élevé et de cholestérol des lipoprotéines de haute densité (HDL) bas que les hommes non obèses. Les hommes ayant une obésité centrale étaient plus susceptibles d'avoir des triglycérides élevés, une hypertension et un cholestérol total élevé. Les femmes obèses risquaient davantage d'être hypertendues et d'avoir un taux élevé de cholestérol total, de triglycérides, de cholestérol LDL et un faible taux de cholestérol HDL que les femmes non obèses. Les femmes ayant une obésité centrale avaient une plus forte probabilité d'avoir un taux élevé de triglycérides et un faible taux de cholestérol HDL. Ces résultats mettent en évidence la nécessité d'une éducation concernant le changement de mode de vie en République islamique d'Iran.
\end{abstract}

${ }^{1}$ Endocrine Research Centre, Shaheed Beheshti University of Medical Sciences, Tehran, Islamic Republic of Iran.

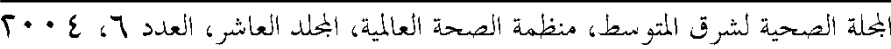




\section{Introduction}

Obesity, determined as excess body fat, is one of the most common health problems worldwide, with an estimated 1.2 billion people affected [1]. Studies in the Islamic Republic of Iran have shown an increasing prevalence of obesity, which is expected to rise in the future due to increasing urbanization [2-4]. The prevalence of obesity and overweight in Tehran among individuals aged over 20 years is $23 \%$ and $40 \%$ respectively [5]. Obese people are more susceptible to chronic non-communicable diseases such as cardiovascular disease (CVD), diabetes and some cancers [6]. In contrast to trends observed in northern Europe and the USA [7], recent data show that mortality from CVD is increasing in the Islamic Republic of Iran [5] and this may be attributed to a rising prevalence of obesity.

Most published papers discussing the relation of CVD and obesity are from the industrialized countries and limited data exists in developing countries. According to our knowledge, no epidemiological study has been published about the relationship between obesity and risk factors for CVD in the Islamic Republic of Iran. The present study was conducted within the framework of the Tehran Lipid and Glucose Study, the design and objectives of which have been published earlier [8]. Briefly, it is a prospective study to determine the prevalence of non-communicable disease risk factors in residents of district 13 of Tehran with the goal of developing guidelines for a healthy lifestyle. This paper reports the findings about the relationship between obesity and selected CVD risk factors in people aged $20-70$ years old.

\section{Methods}

In the Tehran Lipid and Glucose Study, 15005 people aged 3 years and over living in district 13 of Tehran were selected by a multistage cluster random sampling method; 9984 of them were aged 20-70 years. Those with at least one missing variable ( $n$ $=1337$ ) were excluded from the study and thus data were analysed for 8647 participants (3622 men and 5025 women). The proposal for the study was approved by the research council of the Endocrine Research Centre of Shaheed Beheshti University of Medical Sciences and informed written consent was obtained from each subject.

\section{Data collection}

Participants were interviewed privately, face-to-face, by trained interviewers using pre-tested questionnaires. Initially, information on age, educational level and smoking habits was collected. Weight was then measured while the subjects were minimally clothed without shoes using digital scales and recorded to the nearest $100 \mathrm{~g}$. Height was measured in a standing position without shoes using a tape meter while the shoulders were in normal position. Body mass index was calculated as weight $(\mathrm{kg})$ divided by height $\left(\mathrm{m}^{2}\right)$. Waist circumference $(\mathrm{cm})$ was measured at the point of noticeable waist narrowing, and hip circumference $(\mathrm{cm})$ was measured over light clothing at the widest girth of the hip [9]. To avoid subjective error, all measurements were done by the same person. Waist-to-hip and waist-to-height ratios were calculated by dividing waist circumference by hip circumference and height respectively. Obesity was defined by World 
Health Organization criteria as $\mathrm{BMI} \geq 30$ $\mathrm{kg} / \mathrm{m}^{2}[10]$. Waist circumference cut-off points used were $>90 \mathrm{~cm}$ for men and $>80$ $\mathrm{cm}$ for women [11]. For waist-to-hip ratio a cut-off value of $>0.9$ was used for men and $>0.8$ for women [11]. The cut-off for waist-to-height ratio was $\geq 50$ for both sexes [12].

\section{Blood pressure measurement}

Before measuring the blood pressure, the participant was asked about tea or coffee consumption, physical activity, smoking and a full bladder (which might elevate blood pressure).

Participants were initially made to rest for 15 minutes. Then a qualified physician measured their blood pressure 2 times in a seated position following 1 initial measurement for determining peak inflation level using a standard mercury sphygmomanometer. Based on the circumference of the participant's arm, a regular adult cuff was chosen. The cuff was placed on the participant's right arm, at the heart level and inflated as rapidly as possible until the cuff pressure was $30 \mathrm{mmHg}$ above the level at which the radial pulse disappeared. There was at least a 30 -second interval between these 2 separate measurements; thereafter the mean of 2 measurements was considered as the participant's blood pressure. The systolic blood pressure was defined as the appearance of the first sound (Korotkoff phase 1) and diastolic blood pressure was defined as the disappearance of the sound (Korotkoff phase 5) during deflation of the cuff at a $2-3 \mathrm{~mm}$ per second decrement rate of the mercury column.

Hypertension was defined as systolic blood pressure $\geq 140 \mathrm{mmHg}$ or diastolic pressure $\geq 90 \mathrm{mmHg}$ or current treatment for hypertension, according to the criteria of the Joint National Committee on Preven- tion, Detection, Evaluation and Treatment of High Blood Pressure (JNC-VI) [13].

\section{Serum lipid analysis}

A blood sample was drawn between 07.00 and 09.00 hours into vacutainer tubes from all study participants after a 12-14 hours overnight fast. Blood samples were taken in a sitting position according to the standard protocol and centrifuged within 30 to 45 minutes of collection. All blood lipid analyses were done at the Tehran Lipid and Glucose Study research laboratory on the day of blood collection. The analysis of samples was performed using a Selectra 2 auto-analyser (Vital Scientific, Spankeren, Netherlands). Total cholesterol and triglyceride kits (Pars Azmoon, Islamic Republic of Iran) were used. Total cholesterol (TC) and triglycerides (TG) levels were assayed using enzymatic colorimetric tests with cholesterol esterase and cholesterol oxidase and glycerol phosphate oxidase respectively. High-density lipoprotein cholesterol (HDL-C) was measured after precipitation of the apolipoprotein B-containing lipoproteins with phosphotungstic acid. Lowdensity lipoprotein cholesterol (LDL-C) was calculated from serum TC, TG and HDL-C using the Friedwald formula [14]. It was not calculated when TG concentration was $>400 \mathrm{mg} / \mathrm{dL}$.

Assay performance was monitored every 20 tests, using the lipid control sera Precinorm (for normal range) and Precipath (for pathological range) wherever applicable (Boehringer Mannheim, Germany). The Calibrator for Automated Systems (Boehringer Mannheim, Germany) was used to calibrate the Selectra 2 autoanalyser for each day of laboratory analyses. All samples were analysed when internal quality control met the acceptable criteria. 
Inter- and intra-assay coefficients of variation were $2.0 \%$ and $0.5 \%$ for $\mathrm{TC}$ and $1.6 \%$ and $0.6 \%$ for TG respectively. Cutoff points corresponding to Adult Panel Treatment III criteria [15] for borderline high TC, TG, LDL-C and low HDL-C levels were used to define high TC $(\geq 200 \mathrm{mg}$ / dL), high TG ( $\geq 150 \mathrm{mg} / \mathrm{dL})$, high LDL-C $(\geq 130 \mathrm{mg} / \mathrm{dL})$ and low HDL-C $(<40 \mathrm{mg} /$ dL). TC/HDL-C ratio $>4$ was also considered as an adverse serum lipid profile [16].

\section{Statistical analysis}

The participants were divided into 5 age groups; 20-29, 30-39, 40-49, 50-59 and 60-70 years. Statistical analysis was performed with an IBM computer using SPSS, version 9.05 statistical software package, and data were presented as mean, standard deviation (SD) and percentages. The agespecific distributions for high TC, high TG, high LDL-C and low HDL-C were calculated separately for males and females. Bivariate analysis was carried out, using the odds ratio (OR) to test for associations between obesity indicators and CVD disease risk factors. An OR with a $95 \%$ confidence interval that did not include the value of 1.00 in its range was considered statistically significant. For each cardiovascular risk factor, logistic regression models were run. Confounding variables such as age, educational level and smoking habits were included as covariates in all models.

\section{Results}

\section{Prevalence of obesity and CVD disease risk factors}

Of the 8647 participants, 2015 were obese $\left(\mathrm{BMI} \geq 30 \mathrm{~kg} / \mathrm{m}^{2}\right)$, giving an overall prevalence of obesity of $23.3 \%$. A higher proportion of women were obese $(1487,29.6 \%)$ than men $(528,14.6 \%)(P<0.01)$. A further $3459(40.0 \%)$ participants were over- weight (BMI $25-<30 \mathrm{~kg} / \mathrm{m}^{2}$ ), slightly more men $(1534,42.4 \%)$ than women $(1925$, $38.3 \%)$. The highest rate of obesity in both sexes was observed in the 50-59- years age group. The prevalence of obesity increased with age up to 60 years in males and females.

The mean (SD) of anthropometric indices by sex and age group are presented in Table 1. Although BMI was similar for men and women in the 20-29 years age group, men had lower BMI and waist-to-height ratio and higher waist-to-hip ratio than women of other age categories. Men aged 20-29 and 30-39 years had higher waist circumferences than women of corresponding age groups. Men over 40 years had lower waist circumferences than women. For all age groups of men, the mean BMI was approximately $2 \mathrm{~kg} / \mathrm{m}^{2}$ lower than for women, waist-to-height ratio was 4 units lower and waist-to-hip ratio was 0.08 greater. The highest BMI was in the 50-59-years age category in both sexes, whereas for the anthropometric indices BMI was highest in the 60-70-years category.

The prevalence of CVD disease risk factors is shown in Figure 1. For men, high $\mathrm{TC} / \mathrm{HDL}$ was the most prevalent risk factor and for women it was high TC. An increase in prevalence of all risk factors was seen with increasing age, with the exception of a slight drop in the rate of high TG and low HDL-C in the older age groups, in both males and females.

The prevalence of high LDL-C and high TC in the 20-29-years group and hypertension in the 30-39-years group was the same in both sexes. However, among those aged $<40$ years, men had a higher prevalence of risk factors compared with women of the same age, and among participants $>50$ years, women had a higher prevalence of all CVD disease risk factors, except for low HDL-C and high TC/HDL as compared 


\begin{tabular}{|c|c|c|c|c|c|}
\hline \multicolumn{6}{|c|}{ astern Mediterranean Health Journal, Vol. 10, No. 6, 2004} \\
\hline \multicolumn{6}{|c|}{$\begin{array}{l}\text { Table } 1 \text { Mean body mass index, waist circumference, waist-to-hip ratio and waist- } \\
\text { to-height ratio by sex and age categories in the Tehran Lipid and Glucose Study }\end{array}$} \\
\hline \multirow{2}{*}{$\begin{array}{l}\text { Age group } \\
\text { (years) }\end{array}$} & \multirow{2}{*}{$\begin{array}{c}\text { No. of } \\
\text { subjects }\end{array}$} & \multicolumn{4}{|c|}{ Mean (SD) values } \\
\hline & & $\begin{array}{c}B M I \\
\left(m g / k g^{2}\right)\end{array}$ & $\begin{array}{l}\text { Waist } \\
\text { circumference } \\
\text { (cm) }\end{array}$ & $\begin{array}{l}\text { Waist-to- } \\
\text { hip ratio }\end{array}$ & $\begin{array}{c}\text { Waist-to- } \\
\text { height ratio }\end{array}$ \\
\hline \multicolumn{6}{|c|}{ Men } \\
\hline $20-29$ & 762 & $24.0(4.4)$ & $81.5(11.3)$ & $0.85(0.06)$ & $47.0(6.6)$ \\
\hline 30-39 & 957 & $25.9(4.0)$ & $87.5(10.8)$ & $0.90(0.06)$ & $51.0(6.3)$ \\
\hline $40-49$ & 708 & $26.1(3.8)$ & $89.7(10.3)$ & $0.92(0.06)$ & $52.9(6.1)$ \\
\hline $50-59$ & 569 & $26.5(3.8)$ & $91.8(10.4)$ & $0.94(0.06)$ & $54.7(6.2)$ \\
\hline $60-70$ & 626 & $26.2(3.7)$ & $92.3(10.5)$ & $0.95(0.06)$ & $55.5(6.2)$ \\
\hline All & 3622 & $25.7(4.1)$ & $88.2(11.4)$ & $0.91(0.07)$ & $51.9(7.0)$ \\
\hline \multicolumn{6}{|c|}{ Women } \\
\hline 20-29 & 1208 & $24.1(4.5)$ & $77.8(11.0)$ & $0.77(0.06)$ & $48.8(7.0)$ \\
\hline 30-39 & 1324 & $27.2(4.6)$ & $85.1(11.1)$ & $0.81(0.07)$ & $54.0(7.2)$ \\
\hline $40-49$ & 1040 & $29.4(4.7)$ & $91.6(11.6)$ & $0.85(0.07)$ & $58.6(7.5)$ \\
\hline $50-59$ & 818 & $29.6(4.6)$ & $94.9(10.8)$ & $0.89(0.07)$ & $61.4(7.1)$ \\
\hline $60-70$ & 635 & $28.7(4.5)$ & $95.0(11.1)$ & $0.91(0.07)$ & $62.3(7.3)$ \\
\hline All & 5025 & $27.5(5.0)$ & $87.5(13.0)$ & $0.83(0.08)$ & $56.0(8.8)$ \\
\hline
\end{tabular}

$B M I=$ body mass index.

$S D=$ standard deviation .

with men. Hypertension and high TC were more prevalent in women in the 40-49years age group whereas high TG, high LDL-C and low HDL-C were more prevalent in men of this age group.

\section{Relationship between obesity and cardiovascular disease}

The relationship of obesity to CVD disease risk factors is presented as odds ratios for men and women in Table 2, controlling for confounding variables such as age, smoking habits and educational levels.

Compared with non-obese men, obese men had a higher chance of being hypertensive $(\mathrm{OR}=2.80)$ and having high $\mathrm{TG}$ $(\mathrm{OR}=1.76)$, low HDL-C $(\mathrm{OR}=1.73)$, high TC $(\mathrm{OR}=1.55)$ and high LDL-C (OR $=1.36$ ). Men suffering from abdominal obesity (high waist-to-hip ratio) had higher 
Hypertension

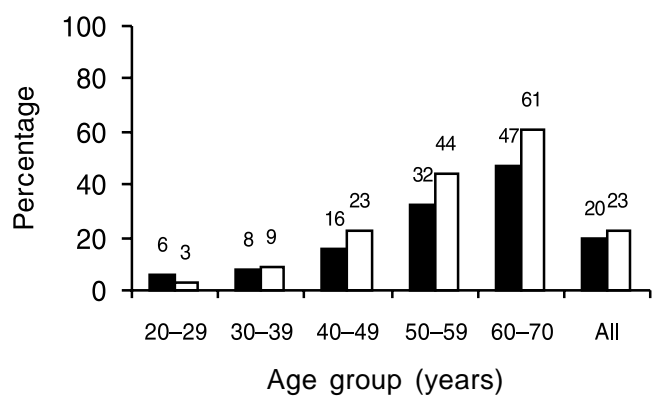

Men $\square$ Women

High TC

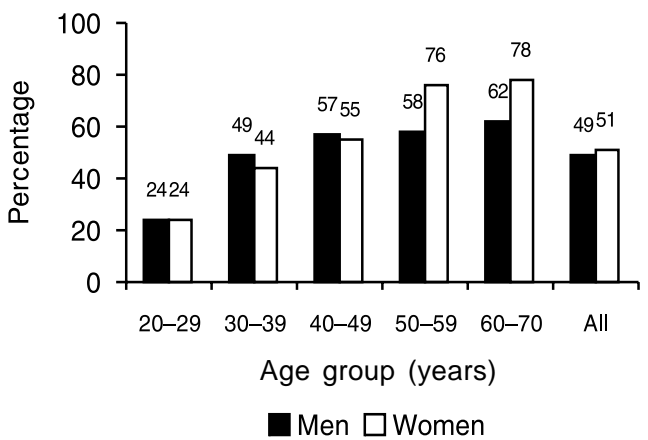

High TG

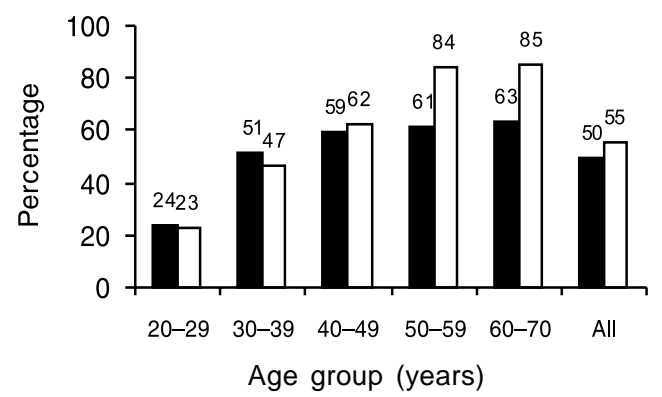

$\square$ Men $\square$ Women
High LDL-C

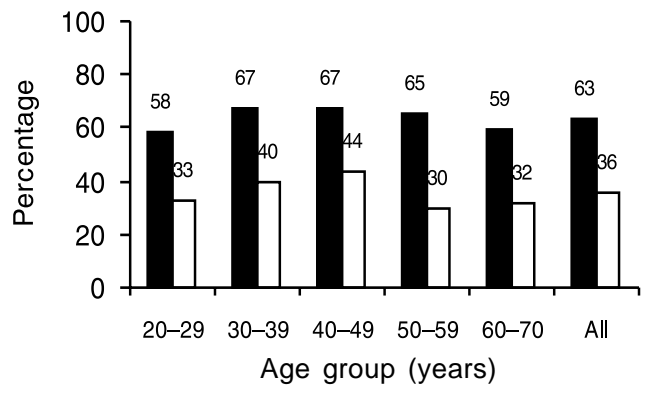

$\square$ Men $\square$ Women

Low HDL-C

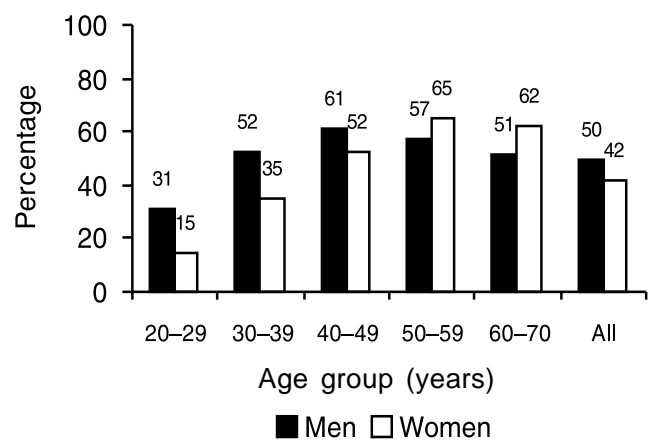

High TC/HDL

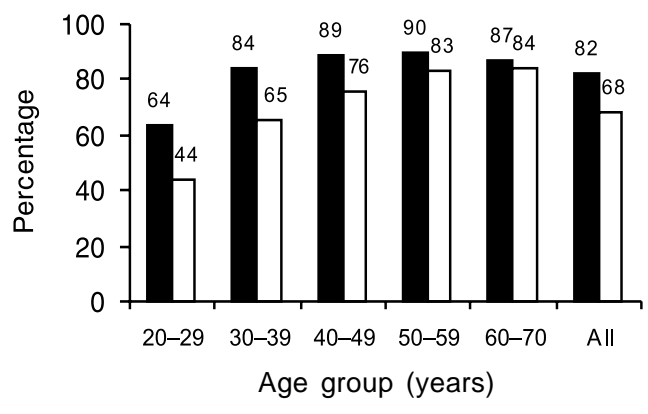

$\square$ Men $\square$ Women

Figure 1 Prevalence of cardiovascular disease risk factors by sex and age categories for 3622 men and 5025 women in the Tehran Lipid and Glucose Study (TC = total cholesterol; TG = triglycerides; $L D L-C=$ low-density lipoprotein cholesterol; $H D L-C=$ high-density lipoprotein cholesterol)

البخلة الصحية لشرق المتو سط، منظمة الصحة العالمية، البخلد العاشر، العدد ج، ع -. 


\begin{tabular}{|c|c|c|c|c|}
\hline \multicolumn{5}{|c|}{ Eastern Mediterranean Health Journal, Vol. 10, No. 6, 2004} \\
\hline \multicolumn{5}{|c|}{$\begin{array}{l}\text { Table } 2 \text { Odds ratio for cardiovascular disease risk factors according to obesity indices in men } \\
\text { and women }\end{array}$} \\
\hline \multirow[t]{2}{*}{ Risk factor } & \multicolumn{4}{|c|}{ Odds ratio $(95 \% \mathrm{Cl})$} \\
\hline & $B M I\left(m g / k g^{2}\right)$ & $\begin{array}{c}\text { Waist } \\
\text { circumference } \\
(\mathrm{cm})\end{array}$ & $\begin{array}{l}\text { Waist-to- } \\
\text { hip ratio }\end{array}$ & $\begin{array}{l}\text { Waist-to- } \\
\text { height ratio }\end{array}$ \\
\hline \multicolumn{5}{|c|}{$\operatorname{Men}(n=3622)$} \\
\hline Hypertension & $2.80(1.88-4.16)^{\star *}$ & $1.09(0.80-1.49)$ & $1.45(1.03-2.03)^{*}$ & $1.15(0.77-1.71)$ \\
\hline High TC & $1.55(1.13-2.12)^{* *}$ & $0.95(0.74-1.20)$ & $1.31(1.04-1.65)^{\star}$ & $1.54(1.18-2.20)^{* *}$ \\
\hline High TG & $1.76(1.28-2.40)^{\star *}$ & $1.08(0.85-1.38)$ & $1.80(1.43-2,26)^{\star *}$ & $1.86(1.42-2.43)^{\star *}$ \\
\hline High LDL-C & $1.36(1.00-1.85)^{\star}$ & $0.80(0.63-1.01)$ & $1.19(0.94-1.50)$ & $1.77(1.35-2.32)^{\star \star}$ \\
\hline Low HDL-C & $1.73(1.25-2.39)^{\star *}$ & $0.93(0.73-1.20)$ & $1.25(0.98-1.58)$ & $1.39(1.05-1.82)^{*}$ \\
\hline High TC/HDL-C & $1.31(0.81-2.14)$ & $1.00(0.66-1.51)$ & $1.57(1.13-2.18)^{\star *}$ & $2.31(1.57-3.39)^{\star *}$ \\
\hline \multicolumn{5}{|c|}{ Women $(n=5025)$} \\
\hline Hypertension & $2.47(1.79-3.41)^{\star *}$ & $0.95(0.63-1.43)$ & $1.11(0.82-1.50)$ & $2.20(1.34-3.61)$ \\
\hline High TC & $1.66(1.32-2.10)^{\star *}$ & $1.03(0.78-1.30)$ & $1.08(0.88-1.32)$ & $1.59(1.19-2.33)^{* *}$ \\
\hline High TG & $2.58(2.05-3.26)^{\star \star}$ & $0.97(0.73-1.29)$ & $1.80(1.46-2.22)^{\star \star}$ & $1.68(1.23-2.29)^{\star \star}$ \\
\hline High LDL-C & $1.41(1.13-1.77)^{\star \star}$ & $0.97(0.74-1.27)$ & $1.08(0.88-1.32)$ & $1.46(1.10-1.94)^{\star \star}$ \\
\hline Low HDL-C & $1.92(1.54-2.40)^{\star *}$ & $1.19(0.91-1.57)$ & $1.56(1.28-1.91)^{\star *}$ & $0.91(0.68-1.21)$ \\
\hline High TC/HDL-C & $2.58(2.03-3.27)^{\star *}$ & $1.00(0.86-1.48)$ & $1.53(1.25-1.87)^{\star *}$ & $1.20(0.91-1.58)$ \\
\hline
\end{tabular}

${ }^{*} \mathrm{P}<0.05 ;{ }^{* *} \mathrm{P}<0.01$ versus normal subjects.

$\mathrm{Cl}=$ confidence interval.

$T C=$ total cholesterol; $T G=$ triglycerides; $L D L-C=$ low-density lipoprotein cholesterol; $H D L-C=$ high-density lipoprotein cholesterol.

\section{Discussion}

The present study, conducted in an urban population of Tehran, showed a high prevalence of CVD disease risk factors and a positive association of these with obesity. In this study, the prevalence of obesity in men was nearly $15 \%$, which was similar to the prevalence reported from Hakimieh district of north-east of Tehran [17] and the rural areas of Tehran [18] but higher than that reported from rural areas of Zanjan (north-west of the country) [19]. Nearly $30 \%$ of women in this study were obese, a rate higher than rural areas of Zanjan [19] and lower than that of Hakimieh [17] and the rural areas of Tehran [18]. The total prevalence of overweight and obesity in our population was $63.3 \%$, which shows the increasing trend of overweight and obesity in Tehran compared with previous reports from this city $[20,21]$.

In the present study, $20 \%$ of men and $23 \%$ of women were hypertensive and the prevalence of hypertension increased with age. In some studies in the Islamic Republic of Iran the prevalence of hypertension was different from our study [22-24]. The prevalence in our study is also higher than that reported in Eastern Mediterranean countries [25] and is approximately equal to the prevalence of American [13] and European [26] countries. This difference may be due to the age of the subjects and envi-

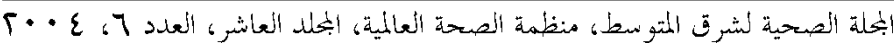


ronmental and cultural conditions. Moreover, the sample size used in the present study is larger than previous studies. There is a wide range of prevalence of hypertension in other reports in the Islamic Republic of Iran. Many factors such as heredity, environment, intake of sodium, calcium and other ions, salt sensitivity, renin levels and insulin resistance have long been assumed to be important in the genesis of hypertension [27]. The higher prevalence in this study compared with previous studies may also be attributed to recent socioeconomic changes in our country.

This study showed a high prevalence of dyslipidaemia in a Tehran population. Fifty per cent of men had high TC and 50\% had high TG. The prevalence of these 2 risk factors was $55 \%$ and $42 \%$ in women respectively. The prevalence of high LDL-C was $49 \%$ for men and $51 \%$ for women and that of low HDL-C was $63 \%$ and $36 \%$ respectively. Using different cut-off points in this study makes it difficult to compare the results with those of other studies. Previous results obtained from the Tehran Lipid and Glucose Study [28], however, showed that lipid disorders in Tehran were more prevalent than in Turkey [29], Canada [30] and England [31]. This may be attributed to lifestyle changes in the Tehran population, such as better availability of food, increasing consumption of high fat foods and lower levels of physical activity.

Assessing the risk for the presence of major CVD risk factors in adults, especially young adults, is of particular importance since it allows us to easily identify those at high risk for development of clinical CVD later in life. In this context, anthropometric measurements that provide obesity indices such as BMI, waist circumference, waistto-hip ratio and weight-to-height ratio are useful non-invasive methods of obtaining information on CVD risk. The results of this study showed that all anthropometric indices used, except for waist circumference, were related to higher levels of CVD disease risk factors.

The lack of association of waist circumference, which showed no relationship with CVD risk factors either in men or women, may be attributed to the site of waist measurement, because past research has showed that the location of waist measurement affects the relation of central obesity to CVD risk factors [32,33]. In this study, waist circumference was measured at the point of noticeable waist narrowing, which may have resulted in lower waist circumference values than might be obtained using other common sites of measurement. The WHO Expert Committee on Physical Status recommend measurement at a point midway between the lower rib and the iliac crest [34]; however, the National Health and Nutrition Examination Survey guidelines recommend a point just above the right ileum [35], and the North American Association for the Study of Obesity and the National Heart, Lung and Blood Institute recommend the right iliac crest [36]. The lack of an international standard for waist circumference measurements is unfortunate, and makes comparison with other studies difficult. We believe that the waist measurement at the narrowest point offers greater ease of acceptance and interpretation by the public and may facilitate self-measurement in addition to clinical use. Another explanation for the lack of relationship between waist circumference and CVD risk factors in the present study is the complex relationship between anthropometric indices and lifestyle-related factors such as smoking and physical activity. In this study, the effect of smoking was controlled, but physical activity, which was not assessed, remains a confounding variable. The other possibility is that the

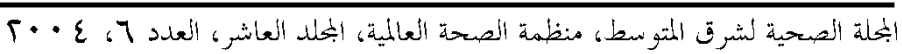


power of waist circumference for predicting disease risk is population-dependent [37] and could vary from race to race [38].

Our findings of a relationship between obesity (high BMI, high waist-to-height ratio and high waist-to-hip ratio) and CVD disease risk factors (hypertension, cholesterol and triglycerides levels) in the Islamic
Republic of Iran are in line with studies from other countries [39-41]. This should be kept in mind especially by Iranian health policy-makers for the implementation of appropriate interventions to curtail the rising trend of obesity and cardiovascular disease.

\section{References}

1. Garrow JS. Obesity. In: Garrow JS, James WPT, Ralph A, eds. Human nutrition and dietetics, 10th ed. Edinburgh, Churchill Livingstone, 2000:527-47.

2. Ayatollahi SM, Carpenter RG. Height, weight, BMI and weight-for-height of adults in southern Iran: how should obesity be defined? Annals of human biology, 1993, 20:13-9.

3. Azizi F et al. Dietary factors and body mass index in a group of Iranian adolescents: Tehran lipid and glucose study-2. International journal for vitamin and nutrition research, 2001, 71:123-7.

4. Pishdad GR. Overweight and obesity in adults aged 20-74 in southern Iran. International journal of obesity and related metabolic disorders, 1996, 20:963-5.

5. Azizi P. Tehran Lipid and Glucose Study. The final report of first phase, 1 st ed. Tehran, Endocrine Research Centre, 2001:68.

6. Pi-Sunyer FX. Obesity. In: Shils $M$ et al., eds. Modern nutrition in health and disease, 9th ed. Baltimore, Lippincott Williams and Wilkins, 1999:1395-419.

7. Kromhout D. Epidemiology of cardiovascular diseases in Europe. Public health nutrition, 2001, 4(2B):441-57.

8. Azizi F et al. Tehran Lipid and Glucose Study (TLGS): rationale and design. Iranian journal of endocrinology and metabolism, 2000, 2:77-86.
9. Jelliffe DB, Jelliffe EFP. Community nutritional assessment. Oxford, Oxford University Press, 1989:56-110.

10. Obesity: preventing and managing the global epidemic. Report of a WHO Consultation on Obesity. Geneva, World Health Organization, 2000 (WHO Technical Report Series, No. 894).

11. Dobbelsteyn $\mathrm{C}$ et al. A comparative evaluation of waist circumference, waistto-hip ratio and body mass index as indicators of cardiovascular risk factors. The Canadian Heart Health Surveys. International journal of obesity and related metabolic disorders, 2001, 25:652-61.

12. Ko $\mathrm{G}$ et al. Prediction of hypertension, diabetes, dyslipidaemia or albuminuria using simple anthropometric indexes in Hong Kong Chinese. International journal of obesity and related metabolic disorders, 1999, 23:1136-42.

13. The sixth report of the Joint National Committee on Prevention, Detection, Evaluation and Treatment of High Blood Pressure. Archives of internal medicine, 1997, 157:2413-46.

14. Friedewald WT, Levy RI, Fredrickson DS. Estimation of the concentration of low-density lipoprotein cholesterol in plasma, without use of the preparative ultracentrifuge. Clinical chemistry, 1972, 18:499-502.

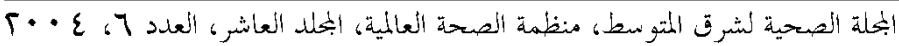


15. Third Report of the Expert Panel on Detection, Evaluation, and Treatment of High Blood Cholesterol in Adults (Adult Treatment Panel III) executive summary. Journal of the American Medical Association, 2001, 285:2486-97.

16. Morar $\mathrm{N}$ et al. Ambulatory blood pressure and risk factors for coronary heart disease in black and Indian medical students. Journal of cardiovascular risk, 1998, 5:313-8.

17. Mirmiran P, Azizi F. Obesity. In: Azizi F, Hatami $\mathrm{H}$, Jangorbani $\mathrm{M}$, eds. Epidemiology and control of prevalent disease in Iran, 2nd ed. Tehran, Eshtiagh Press, 2001: 56-69 [in Persian].

18. Azizi F. Assessing the epidemiological indices of type 11 diabetes mellitt,s in adults aged over 30 years in rural areas of Tehran province. Final report. Tehran, Research Department, Ministry of Health, 1998 [in Persian].

19. Sharifi F, Azizi F. The prevalence of hyperlipidemia, overweight and blood pressure in diabetic and TOT patients and their comparison to healthy subjects in rural areas of Zanjan. Research in medicine, 1997, 21:41-50 [in Persian].

20. Bagheri F. Epidemiology of obesity in adults aged 20-50 years, residents of district-19 Tehran [MSc Thesis]. Tehran, National Nutrition Research Institute, 1996.

21. Kavian F et al. Obesity prevalence, fat distribution and associated factors in women. Pajohandeh, 2001, 5:459-63 [in Persian].

22. Fakhrzadeh $\mathrm{H}$, Poorebrahim R, Amininik S. Prevalence of arterial hypertension in Bushehr. Iranian heart journal, 1998, 1:215.

23. Barzigar A, Shojaei M, Akbar MH. Survey of blood pressure standard in north Iran. Iranian health, 1998, 1:121.
24. Maleki $\mathrm{M}$ et al. Prevalence of cardiovascular risk factors in Tehran: Healthy Heart Project. Iranian heart journal, 1998, 1: 130.

25. Cardiovascular disease: prevention and control. Technical paper. Alexandria, World Health Organization Regional Office for the Eastern Mediterranean, 1998 (http://www.who.int/dietphysicalactivity/ media/en/gsfs_cvd.pdf, accessed 9 January 2005).

26. Prevention of coronary heart disease in clinical practice. Recommendations of the Second Joint Task Force of European and Other Societies on coronary prevention. European heart journal, 1998, 19:1434-503.

27. Krummel DA. Medical nutrition therapy in hypertension. In: Mahan LK, EscottStump S, eds. Krause's food, nutrition and diet therapy, 11th ed. Philadelphia, WB Saunders, 2004:900-15.

28. Azizi $F$ et al. Serum lipid levels in an Iranian adults population: Tehran lipid and glucose study. European journal of epidemiology, 2003, 18:311-9.

29. Onat A et al. Plasma lipids and their interrelationship in Turkish adults. Journal of epidemiology and community health, 1992, 46:470-6.

30. MacLean DR et al. Plasma lipids and lipoprotein reference values and the prevalence of dyslipoproteinemia in $\mathrm{Ca}$ nadian adults. Canadian Heart Health surveys Research Group. Canadian journal of cardiology, 1996, 15:434-44.

31. Shetterly SM et al. Waist-hip-ratio measurement location influences associations with measure of glucose and lipid metabolism: the San Luis Valley Diabetes Study. Annals of epidemiology, 1993, 3:259-9.

32. Houmard JA et al. An evaluation of waist to hip ratio measurement methods in re- 
lation to lipid and carbohydrate metabolism in men. International journal of obesity, 1991, 15:181-8.

33. Shetterly SM et al. Waist-hip ratio measurement location influences associations with measure of glucose and lipid metabolism. The San Luis Valley Diabetes Study. Annals of epidemiology, 1993, 3:259-9.

34. Physical status: the use and interpretation of anthropometry. Report of a WHO Expert Committee. Geneva, World Health Organization, 1995 (WHO Technical Report Series, No. 854).

35. Chumlea NC, Kuczmarski RJ. Using a bony landmark to measure waist circumference. Journal of the American Dietetic Association, 1995, 95:12.

36. North American Association for the Study of Obesity/National Heart, Lung and Blood Institute. The practical guide. Identification, evaluation and treatment of overweight and obesity in adults. Bethesda, Maryland, National Institutes of Health, 1998 (NIH Publication Number 00-4084).
37. Molarius A, Seidell JC. Selection of anthropometric indicators for classification of abdominal fatness: a critical review. International journal of obesity and related metabolic disorders, 1998, 22: 719-27.

38. Gallagher D et al. How useful is body mass index for comparison of body fatness across, age, sex and ethnic groups? American journal of epidemiology, 1996, 143:228-39.

39. Hu FB et al. Body mass index and cardiovascular risk factors in a rural Chinese population. American journal of epidemiology, 2000, 151:88-97.

40. Ko GT et al. Simple anthropometric indexes and cardiovascular risk factors in Chinese. International journal of obesity and related metabolic disorders, 1997, 21:995-1001.

41. Huang KC et al. Four anthropometric indices and cardiovascular risk factors in Taiwan. International journal of obesity and related metabolic disorders, 2002, 26:1060-8.

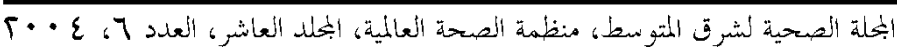

